\title{
Determinants of Dividend Pay-Out Policy of Listed Non-financial Firms in Malaysia
}

\author{
Hussain Tahir ${ }^{1}$, Ridzuan Masri ${ }^{1} \&$ Mahfuzur Rahman ${ }^{2}$ \\ ${ }^{1}$ International University of Malaya-Wales, Kuala Lumpur, Federal Territory of Kuala Lumpur, Malaysia \\ ${ }^{2}$ Faculty of Business and Accountancy, University of Malaya (UM), Kuala Lumpur, Malaysia \\ Correspondence: Mahfuzur Rahman, Faculty of Business and Accountancy, University of Malaya (UM), Kuala \\ Lumpur, Malaysia.
}

Received: October 29, 2019

Accepted: December 3, 2019

Online Published: March 16, 2020

doi:10.5430/ijfr.v11n2p68

URL: https://doi.org/10.5430/ijfr.v11n2p68

\begin{abstract}
This research paper scrutinizes to recognize the determinants of dividend pay-out. A total of 203 Malaysian non-financial firms representing from various industries were scrutinized over a period of fourteen financial years covering 2005 to 2018. The panel data form specified the time series and cross-sectional nature used for this research paper. Fixed effect and random effects description techniques were used for investigation. The outcomes reveal a statistically significant and positive association between corporate board size, ROA and dividend pay-out. However, financial leverage has a negative and significant relationship with dividend policies. But the study reveals a statistically insignificant and positive relationship between board diversity and dividend pay-out. This paper suggestions insight to policy-makers of emerging economies interested in the development of the financial structure mechanism. This study guides companies in the structure and employment of dividend pay-out.
\end{abstract}

Keywords: dividends policy, non-financial companies, board size, board diversity, financial leverage

\section{Introduction}

Firms that perform well, generate high revenue. There are many ways in which such income can be used. There is the propensity for companies to reinvest its profits in current business infrastructure; this model comes from residual theory of dividend. Firms give dividend because of investor pressure, dividend is a reward for financial investment (Benlemlih, 2019; Black, 1976b; Kulathunga \& Azeez, 2016). There is a question, is all income of the firms paid in dividend or some part of the profit is distributed as a dividend? The dividends pay-out policy was the topic of several studies of research for a various period from earlier to current (Amidu, 2006; Benlemlih, 2019; Inyiama \& Inyiama, 2015; Jebaraj, 2019; Linter, 1956; Rajverma et al., 2019). The dividend pay-out is a concern of all firm's stockholder from many decades; however, dividend pay-out shows its importance after the work of Black (1976b) in corporate financial management. There are several debates surrounding dividend pay-out in corporate finance. Black (1976a) reveals, we also look at the number of beneficial images, so think like a puzzle, with the pieces that sit just do not fit together.

There is a question, why firms announce dividend and some do not announce dividends is still challenging to clarify. Therefore, dividend pay-out policy remains provocative. Some scholars like Amidu (2006) believe that setting pay-out comprises critical decision making and there are no single descriptions of dividend that there has been emerging concern. With increasing corporate structure, competitiveness and complexity around the world, it is difficult to identify one factor that has a greater impact on dividend. There is no single reason to believe a corporate payout policy is operating under the same purpose (Brown \& Martinsson, 2016; Brook, Charlton, \& Hendershott, 1998).

Researchers follow different methods of existence hypothetical and experiential, simple to complex models to identify aspects that are probable to have impacts on dividend pay-out. However, new empirical researches have been attentive on developed economies where their corporate features are dissimilar from emerging economies. This research is one of the few experimental studies to focus on emerging market. However, Amidu (2006) examines the performed utlizing data from the firms annual reports registered on the Ghana Stock Exchange throughout for six year. The other research uses OLS and Logistic regression models to analysis the estimation in Pakistani KSE 
100-index companies for the period of ten years from 2005 to 2014. Corporate board attributes and financial leverage were engaged as independent variables, dividend payout as dependent variables. It is determined that the corporate board size, financial leverage and ROE are statistically significant and impact the dividend pay-out (Ahmad, khan, \& khan, 2019). The other researche is conducted to recognize the effect of capital strucyure on pay-out policy, the research apply a panel data analysis of 141 companies registered on Kuala Lumpur Stock exchange for five years from 2009 to 2013 (Ali, Mohamad, \& Baharuddin, 2018).

Though, it is significant to note that firms that are registered may behavior in a different way from those that are not registered since a policy may impact on its market. In this regards the investigators examine the causes or determinant of dividends pay-out of registered non-financial firms in Malaysia. The non-financial firms with different industry in Malaysia have seen marvelous enhanced and improved its technology and operation over the last decade, that is why Malaysia has improved its exports. This led to the arrival and establishment of non-financial firms and some were registered with the Kuala Lumpur Stock Exchange in BURSA Malaysia. It has been observed that when the share of non-financial firms is released, and purchased due to better profit opportunities. There may be higher ROE or dividend payments on such stocks. For this reason, researchers want to study the dividend factors of non-financial firms listed on Kuala Lumpur Stock Exchange (BURSA Malaysia) during the last fourteen years. This study is likely to guide corporate executives in emerging economies, about the valid and fully profitable payment strategies. It will also be helpful for investors in the financial sector to prepare their investment portfolio. This research paper will contribute to CG law maker for future strategies.

\subsection{Objectives of the Study}

Objectives of the research paper:

Recognize the variables with likely to impact on the dividends and pay-out policy of non-financial firms in Malaysia and determine the association between dividend pay-out policy and the explanatory variables.

\section{Literature Review}

\subsection{Dividend Policy}

Currentlly, dividend payout has become an important decision in corporate finance. Dividend is a portion of the income that stockholders receive. The volume of the profit is categorically identified by the firm's corporate board of members and is generally announce quarterly in the middle of the year or at the end of the year, it depends on the policy of the company. This research paper on dividend pay-out was motivated by (Benjamin \& Biswas, 2019; Chen, Leung, \& Goergen, 2017; Kulathunga \& Azeez, 2016; Miller et al., 1961; Uwalomwa et al., 2015).

However, subsequent investigations that reveal the perfect capital market speculation and the absence of markets such as information asymmetry, tax considerations and agency costs recognize that a lucrative payment policy is certainly important for an organization. In business finance, pay-out policy characterizes one of the most determined topics that researcher wants to investigate. Many researcher have tried to explain the "dividend puzzle" recognized in Black (1976) but unfortunately these investigations have not yet arrived at a mutual explanation. A combination of view consequently exists about why companies announce dividends and whether the assortment of a specific dividend pay-out can impact the worth of an organization. Usually, financial researchers have three categories based on their beliefs about the influence of dividend pay-out on company worth. The first believers believe that dividends announcement have information content: means an increase in the dividend pay-out parallel to increases company worth (Lonie, Abeyratna, Power, \& Sinclair, 1996; McCluskey, 2005). Second researcher panel, thinks an upsurge in ratio of dividend tends to decrease share price because Woolridge and Ghosh (1985) proposes that companies have a dearth of positive net present value projects requiring investment Bell \& Jenkinson (2002); Lasfer (1995) and leads to high tax rates, when the tax on income is high than that a capital gains. The $3^{\text {rd }}$ panel claims the dividend impact has no impact at all on company worth (Kaleem \& Salahuddin, 2006; Uddin \& Chowdhury, 2005).

\subsection{Board Size}

Some theories describe the advantages of small corporate boards. One is cohesiveness, which is helped by smaller boards, there is a positive relationship between group cohesion and firm performance (Evans \& Dion, 2012). Goodstein et al. (1994) reports strategic management, large boards limit the directors' aptitude to pledge strategic communications. Furthermore, Mintzberg et al. (1983) reveal that the board directors' assessments of top administration are more easily manipulated when boards are large.

Empirically, investigations, exploring the association within board size and dividend pay-out policy are limited, consequently contributing a better chance to provide to research. Getting of initial investigations compared to bond 
within board size and dividend pay-out is, though miscellaneous (Ghasemi, \& Keivani, 2013; Litai, 2011; Mansourinia, 2013; Nicholson \& Kiel, 2003; Ozkan, A., \& Mancinelli, 2006). Ozkan \& Mancinelli (2006) described a distinctive sequence recommended that companies with bigger boards lead to be linked with prominent managerial monitoring, and therefore lowering levels of agency conflicts. Likewise, conclusions of Mansourinia et al. (2013) proposed a sure connection between board size and earnings pay-out strategy. In extension, Nicholson \& Kiel (2003) summarized a certain influence of board size on dividend pay-out strategy with a representation of Australian firms. Additional, applying data of 1,056 A-share registered companies in Shanghai and Shenzhen stock exchange across an ending-pitch of seven years 2001 to 2008. Litai (2011) observed that size of a board is arbitrarily linked with dividend pay-out policy. Through the opposite, separate investigations produce detailed an adverse impact of board size on dividend pay-out policy. As an instance, conclusions from Ghasemi, \& Keivani (2013) advocated a contradictory and vital connection inboard size and dividend pay-out with 81 Iranian registered companies at Teheran Stock Exchange of 2005 to 2011.

\subsection{Board Diversity}

Historically, most of the boards of directors mostly included male corporate board members. In these days, there is a robust quarrel for taking more female executives to deliver different arguments which may improve the ability of decisions making and firm dividend pay-out policy. There is a relationship between board diversity and dividend pay-out, financial performance, finishing that female board sign is positive relationship with dividend policy (Byoun, Chang, \& Kim, 2016; Nielsen \& Huse, 2010). Board diversity also effective in companies to emphasis additional on CSR (Shaukat et al., 2016).

Some researches that explain sexuality difference has a definite relationship with performance and financial decision making (Carter, Simkins, \& Simpson, 2003). Through further remarkable researches assume that sexuality heterogeneity \& performance are not associated with as whole (Oxelheim, Randoy, \& Thomsen, 2006; Zahra, Shaker A., 1988). So, board diversity is a relationship with dividend pay-out. Furthermore, Hutchinson et al. (2015) reveal that board gender diversity is positively related to company performance. On the other side, Rose (2007) reveal insignificant connotation between lady directors and company performance of registered company's in Denmark.

\subsection{Financial Leverage}

Financial leverage "Total debt dividend by total assets" it is measuring the debt, equity ratio, how much external debt firms has? Al-Najjar \& Hussainey (2009). Financial complexity of a company is outstanding to its high financial leverage ratio (Zeng, 2003). Financial leverage has found a negative impact on dividend pay-out in the number of studies (Abor \& Bokpin, 2010; Al-Kuwari, 2009; Amidu, 2006). The possession arrangement and the firm's financial assets have a significant influence on financial consultancy. Some way to exploit its worth is by increasing the mixture of loan and equity investment to sponsorship its assets making cash flow for the firm. Financial leverage is used as a failure to pay timely sign and has a positive association with the cost of finance, consequently paying dividends can boost the financial complexity of a company outstanding to its high leverage ratio (Zeng, 2003). The consequences demonstrate that there is a negative connection between financial leverage and dividend pay-out policy (Fenn \& Liang, 2001).

Nash et al. (2003) also, rope the quarrel ascending from the addition of financing contracts to reduce dividend pay-out by investors. Moreover, Ozdagli (2009) identify the important association between the dividends bid with the firm's linked to capital structure (financial leverage). In reality, the leverage height of the firm will replicate changes in income to its investors. There is a negative connection between financial leverage and dividend policy. An upsurge in a financial leverage ratio of the firm, automatically effect negatively on dividend payout, as a firm have to put up with the outlay to pay back their loans. Though, The association among capital structure and firm dividend policy was encouraging, the most favorable financial leverage ratio will capable to announce a high dividend (Al-Kuwari, 2009).

\subsection{Return on Assets}

The coeprate dividend announcments is baised on firm's profits, thus, it is rational to consider the return on assets as a verge aspect. The level of ROA is a one of the most significant aspects that may impact the company's' dividend pay-out decisions. ROA can be definite as the ability of the company resources to generate reasonable profit or net income divided by total assets. The company income volume determines the ratio of dividend pay-out for the years. Dividend pay-out has been largely and strongly parallel company profitability (Al-Kuwari, 2009). Profitable companies are probably most likely to pay dividend compared to non-profitable companies (Ahmed \& Javid, 2008; Eriotis \& Vasiliou, 2004). Therefore, Pruitt \& Gitman (1991) disclose that in every year to year dividend on profits 
bring to a close that profit is significant factors that impact dividend payout policy. The dividend payout policy be a subject of existing profits of the company (Baker \& Powell, 2000). The increase in the profits is a sign for high dividends announcement, and profitability of the company plays a significant role in growing the level of dividend (Al-Najjar \& Hussainey, 2009). Profitability is maintained by signalling theory as the company wants to increase the standing of its performance.

However, the executives are conscious about possible future bad days they want to pay less dividend to hold some cash (Al-Kuwari, 2009). Besides, when a company less investment opportunity it pays a bigger dividend payout from the profit made (Kowalewski, Stetsyuk, \& Talavera, 2008; Chen et al., 2019). In the classic study, a company's net earnings are the critical determinant of dividend changes (Buchanan et al., 2017; Linter, 1956). For this reason, Al-Malkawi (2007) concluded that profitability is an important determinant of the level of profit paid by companies.. Reddy (2006) reveal that paying of dividends show the company profitable. A negative sign of dividend pay-out in descriptive statistics shows that companies in Malaysia pay a dividend when companies were in loss, which means companies pay a dividend from their previous profit to maintain their position in the stock market.

\section{Research Methdology}

Subsequently the paper searching to recognize variables probable to have an impact on dividend pay-out policy. The main data used for the study was taken from the respective firm's annual reports that are directly downloaded from BURSA Malaysia website. The financial data is collected from Thomson Reuter DataStream. For collection of information study downloaded the firm's annual reports from 2005 to 2018. Study considered 203 non-financial firms registered on Kuala Lumpur Stock Exchange, BURSA Malaysia, these were made up of 796 firms after deduction of financial firms. There three criteria for selection of firm for specific research first, Firms annual reports availability for the period of 2005 to 2018. Second, financial data availability of required registerd non-financial company's at bursa Malayssia. Third, non-financial firm registered on BURSA Malaysia before 2005.

\subsection{Model Specification}

Since the study seeks to determine the variables impact dividends pay-out of listed non-financial firms registered on Kuala Lumpur Stoch Exchange (BURSA Malaysia) over fourteen years, the research paper is practicing a time-series and cross-sectional panel data regression technique. The panel data from the non-financial firms were collected dircttly from Thomson Reuture dataStream and respective firm annual reports which are diectily downloaded from BURSA Malaysia website.

\subsubsection{The Research Paper Model}

$$
\mathrm{DPR}_{\mathrm{it}}=\beta_{0}+\sum \beta_{\mathrm{i}} \mathrm{X}_{\mathrm{it}}+\varepsilon_{\mathrm{it}}
$$

$\mathrm{DPR}_{\mathrm{it}}$ is stand for dividend payout ratio of firm i at time t. $\beta_{0}$ is the intercept of an equation $\beta_{i}$, is uses for coefficients of $\mathrm{X}_{i t}$ variables. $\mathrm{X}_{\mathrm{it}}, \mathrm{x}$ stands for independent variables and $\varepsilon$, is used for error term.

Essentially, conversions of LSM into specified model;

$$
\mathrm{DPR}_{i t}=\beta_{0}+\beta_{1} \mathrm{~B}_{-} \text {size }_{\mathrm{it}}+\beta_{2} \mathrm{~B}_{-} \operatorname{div}_{\mathrm{it}}+\beta_{3} \mathrm{Flev}_{\mathrm{it}}+\beta_{4} \mathrm{ROA}_{\mathrm{it}}+\varepsilon_{\mathrm{it}}
$$

Table 1. Definition of variables and expected signs

\begin{tabular}{lll}
\hline Variable & Definition & Expected signs \\
\hline DPR_NI & Cash dividend/net income & \\
\hline B_size & Number of the board of directors & Positive \\
\hline B_div & Number of women/ all board members & Positive \\
\hline Flev & Total debt / total assets & Negative \\
\hline ROA & Net Income / total assets & Positive \\
\hline
\end{tabular}

\section{Results and Discussions}

\subsection{Descriptive Statistics}

Table 2 shows a summary statistic of the variables explaining the dividend payout policy of non-financial firms in Kuala Lumpur Stoch Exchange (BURSA Malaysia). Dividend pay-out means and standard division was averagely 
0.2284(0.4334). The board size means and S.D 7.4233(1.8518) with minimum and maximum board member remains in 3 to 15 . The board diversity mean and S.D stand at $0.0985(0.1174)$. While the financial leverage mean, S.D are 0.1831(1799). ROA mean and S.D stand at 0.0286(0.1815), with minimum and maximum -2.3119 to 5.2805 which very low to very high, it depends on companies' policies.

Table 2. Descriptive statistics

\begin{tabular}{llllll}
\hline & OBS & Mean & Std. Div. & Min & Max \\
\hline DPR & 2,842 & 0.2284 & 0.4334 & -3.6444 & 3.0849 \\
\hline B_size & 2,842 & 7.4233 & 1.8518 & 3 & 15 \\
\hline B_div & 2,842 & 0.0985 & 0.1174 & 0 & 0.5714 \\
\hline Flev & 2,842 & 0.1831 & 0.1799 & 0 & 2.9163 \\
\hline ROA & 2,842 & 0.0286 & 0.1815 & -2.3119 & 5.2805 \\
\hline
\end{tabular}

\subsection{Correlation Analysis}

A correlation matrix is a table viewing correlation coefficients between sets of variables. Each variable (Xi) in the table is correlated with each of the other variables in the table $(\mathrm{Xj})$. This allows you to see which pairs have the highest correlation. If the correlation is 0.8 between two variables, they are positively correlated. Pearson's correlation coefficient can be utilized to assess the association between two or more than two variables. Correlation Matrix is used to identify the correlation between each pair of variables in the dataset. Study uses VIF to investigate the multicollinearity between variables. The Variance Inflation Factor (VIF) and correlation coefficients the repressors' have revealed in Table 3. The VIF and correlation matrix results show negligible multicollinearity among the variables.

The coreltion metrix identify the dividend payout ratio have positive relationship with board size, board iersity and ROA. However, a negative low level corlation is identified with corporate board diversity. The board size has negative and low level of correlation is identified with board diversity and financial leverage but table shows positive and low degree correlation between corporate board size and ROA. Board diversty has postibe correlation with financial leverage and ROA. The table shows negative and moderator correlation between financial leverage and ROA.

Table 3. Correlation matrix

\begin{tabular}{llllllll}
\hline & Veriables & 1 & 2 & 3 & 4 & 5 & VIF \\
\hline 1 & DPR & 1.0000 & & & & 1.05 \\
\hline 2 & B_size & 0.1199 & 1.0000 & & 1.01 \\
\hline 3 & B_div & 0.0309 & -0.0602 & 1.0000 & & 1.01 \\
\hline 4 & Flev & -0.1126 & -0.0074 & 0.0071 & 1.0000 & & 1.03 \\
\hline 5 & ROA & 0.1492 & 0.0573 & 0.0397 & -0.1713 & 1.0000 & 1.04 \\
\hline & OBS & 2,842 & 2,842 & 2,842 & 2,842 & 2,842 & \\
\hline
\end{tabular}

\subsection{Regression Analysis}

Table 4 shows regression anlsysis of study variables in fixed effect and rondom effect model. The outcomes shows, board size, ROA, and FLEV are statistically significant in explaining the dividend payout policy of registered non-financial firms in the Kuala Lumpur Stoch Exchange (BURSA Malaysia). The board diversity negatively impacts the dividend payout in fixed effect. However, board diversity has positive impact on dividend payout policy but statistically insignificant in random effect model. Less impact of board diversity on DPR means the non-financial firms prefer to pay cash dividend. The announcement of a dividend policy depends on the decisions of the corporate board. There is a relationship between corporate board size and dividend pay-out policy (Mansourinia et al., 2013). 
Consistent with study expectation board size positively affects the dividend pay-out. Firm's board size was statistically insignificant in the fixed-effect model. However, the firm's board size was statistically significant in the random-effect model; the positive relatinship results are parallel with studies (Subramaniam et al., 2011; Uwalomwa et al., 2015).

The association between capital structure (financial leverage) and dividend policy is very important to identify. Regressions results identify the association between financial leverage and dividend policy. Statistically significant and relatively negative results are in line with the expectations of the study; when there is less financial leverage, the firm generally pays fewer dividends. Which was already identified by prior studies (Abor \& Bokpin, 2010; Al-Kuwari, 2009; Amidu, 2006).

Return on assets relationship with dividend pay-out is relatively positive and statistically significant, which means increase in ROA parallel to pay-out in non-financial firms of Malaysia. This is already identified from different researches (Byoun, Chang, \& Kim, 2016; Elmagrhi et al., 2016). These results also reveals, the most of the Malaysian firms have pay high dividend on the growth of high return on assets.

Table 4. Regression results

\begin{tabular}{lllll}
\hline Explanatory & Fixed effects & \multicolumn{3}{l}{ Random effects } \\
\hline Variable & Coef. & t-stat. & Coef. & z-stat. \\
\hline B_size & 0.0105 & 1.53 & 0.0180 & $3.16^{* * *}$ \\
\hline B_div & -0.0425 & -0.38 & 0.0349 & 0.38 \\
\hline Flev & -0.0556 & -1.01 & -0.1096 & $-2.15^{* *}$ \\
\hline ROA & 0.01535 & $3.64^{* * *}$ & 0.1854 & $4.46^{* * *}$ \\
\hline Constant & 0.1601 & $2.96^{* * *}$ & 0.1053 & $2.2^{* *}$ \\
\hline & F-test & $5.68^{* * *}$ & Wald chi2(4) & 40.25 \\
\hline & Prob $>\mathrm{F}$ & $* * *$ & Prob > chi2 & $* * *$ \\
\hline & R-sq & 0.1628 & R-sq & 0.1668 \\
\hline
\end{tabular}

\section{Conclusion}

The study was designed at founding the variables influance dividend pay-out registered non-financial companies of BURSA Malaysia. The outcomes reveals a statistically significant and positive association between board size and dividend payout policy, positive relationship means if firm have large board in size impact the dividend payout policy positively. Large board-size companies announce a higher percentage of profits as a divivdend compared to smaller corporate boards firms. Most Malaysian firms are family-owned and families prefer to assign directors from families they never fallows the corporate goverances roles, may be the that is why the relationship between board diversity and dividend pay-out is statistically insignificant.

On the other side, the firm's financial leverage has a statistically significant and negative association with dividend pay-out, which means high financial leverage leads to less dividend announcement. In fact, when a firm has a higher financial leverage ratio, they have to pay higher interest on the loan, which affects the firm's dividend payoutt policy. Last objective of the study was return on assets relationship with dividend payout policy. There is a positive and statistically significant relationship identified between ROA and dividend payout policy, means when firm ROA is high, the firm announce high dividend payout policy to satisfy the investors and attract more investment to more increase in profits. Thus, the main factors or determinants of dividend pay-out policy of non-financial firms in Kuala Lumpur Stoch Exchange BURSA Malaysia are the board's size, return on assets, financial leverage. Board diversity did not affect significantly on dividend payout policy; however, there is a positive relationship identified. It is recommended that upcoming researches should look at the dividend pay-out policy of financial firms of emerging economy.

\section{Acknowledgment}

We gratefully acknowledge the funding from the Faculty of Business and Law, International University of Malaya-Wales Malaysia Grant \# IUMW/INT-GRANT/COMMITTEE/2019(1). 


\section{References}

Abor, J., \& Bokpin, G. A. (2010). Investment opportunities, corporate finance, and dividend payout policy: Evidence from emerging markets. Study on Economic Finance, 27(3), 180-194. https://doi.org/10.1108/10867371011060018

Ahmad, M. N., Khan, F. U., \& Khan, Y. (2019). Board Composition, Ownership Structure and Dividend Payout Policy: Evidence from PSX-100 Index of Pakistan.

Ahmed, H., \& Javid, A. Y. (2008). The determinants of dividend policy in Pakistan (pp. 1-16). MPRA paper No. 37339. Retrieved from https://mpra.ub.uni-muenchen.de/37339/

Ali, N. Y., Mohamad, Z., \& Baharuddin, N. S. (2018). the impact of ownership structure on dividend policy: evidence of malaysian listed firms. Journal of Global Business and Social Entrepreneurship, 4(10), 35-44.

Al-Kuwari, D. (2009). Determinants of the dividend policy in emerging stock exchanges: The case of GCC countries. Global Economy \& Finance Journal, 2(2), 38-63.

Al-Malkawi, H. (2007). Determinants of corporate dividend policy in Jordan: An application of the Tobit model. Journal of Economic \& Administrative Sciences, 23(2), 44-70. https://doi.org/10.1108/10264116200700007

Al-Najjar, B., \& Hussainey, K. (2009). The association between dividend payout and outside directorships. Journal of Applied Accounting Research, 10(1), 4-19. https://doi.org/10.1108/09675420910963360

Amidu, A., \& Abor, J. (2006). Determinants of dividend payout ratios in Ghana. The Journal of Risk Finance, 7(2), 136-145. https://doi.org/10.1108/15265940610648580

Baker, H. K., \& Powell, G. E. (2000). Determinants of corporate dividend policy: a survey of NYSE firms. Financial Practice and Education, 10, 29-40.

Bell, L., \& Jenkinson, T. (2002). New evidence of the impact of dividend taxation and on the identity of the marginal investor. The Journal of Finance, 57(3), 1321-1346. https://doi.org/10.1111/1540-6261.00462

Benjamin, S. J., \& Biswas, P. (2019). Board gender composition, dividend policy and COD: the implications of CEO duality. Accounting Research Journal, 32(3), 454-476. https://doi.org/10.1108/ARJ-02-2018-0035

Benlemlih, M. (2019). Corporate social responsibility and dividend policy. Research in International Business and Finance, 47, 114-138. https://doi.org/10.1016/j.ribaf.2018.07.005

Black, F. (1976a). The dividend puzzle. The Journal of Portfolio Management, 2(2), 5-8. https://doi.org/10.3905/jpm.1976.408558

Black, F. (1976b). The pricing of commodity contracts. Journal of Financial Economics, 3(1-2), 167-179. https://doi.org/10.1016/0304-405X(76)90024-6

Brook, Y., Charlton, W. T. Jr., \& Hendershott, R. J. (1998). Do firms use dividends to signal large future cash flow increases?. Financial Management, 27(3), 46. https://doi.org/10.2307/3666274

Brown, J. R., \& Martinsson, G. (2016, July 27). Taxing Capital, Stunting Growth? Capital Income Taxes, Costly Equity Finance, and Investment in R\&D. Capital Income Taxes, Costly Equity Finance, and Investment in R\&D. Swedish House of Finance Research Paper, No. 15-14.

Buchanan, B. G., Cao, C. X., Liljeblom, E., \& Weihrich, S. (2017). Uncertainty and firm dividend policy - A natural experiment. Journal of Corporate Finance, 42, 179-197. https://doi.org/10.1016/j.jcorpfin.2016.11.008

Byoun, S., Chang, K., \& Kim, Y. S. (2016). Does Corporate Board Diversity Affect Corporate Payout Policy?. Asia-Pacific Journal of Financial Studies, 45(1), 48-101. https://doi.org/10.1111/ajfs.12119

Carter, D. A., Simkins, B. J., \& Simpson, W. G. (2003). Corporate governance, board diversity, and firm value. Financial Review, 38(1), 33-53. https://doi.org/10.1111/1540-6288.00034

Chen, J., Leung, W. S., \& Goergen, M. (2017). The impact of board gender composition on dividend payouts. Journal of Corporate Finance, 43, 86-105. https://doi.org/10.1016/j.jcorpfin.2017.01.001

Elmagrhi, M. H., Ntim, C. G., \& Wang, Y. (2016). Antecedents of voluntary corporate governance disclosure: A post-2007/08 financial crisis evidence from the influential UK Combined Code. Corporate Governance (Bingley), 16(3), 507-538. https://doi.org/10.1108/CG-01-2016-0006

Eriotis, N., \& Vasiliou, D. (2004). Dividend policy: an empirical analysis of the Greek market. International Business \& Economics Research Journal (IBER), 3(3), 49-58. https://doi.org/10.19030/iber.v3i3.3671 
Evans, C. R., \& Dion, K. L. (2012). Group cohesion and performance: A meta-analysis. Small Group Research, 43(6), 690-701. https://doi.org/10.1177/1046496412468074

Fenn, G. W., \& Liang, N. (2001). Corporate payout policy and managerial. Journal of Financial Economics, 60, 45-72. https://doi.org/10.1016/S0304-405X(01)00039-3

Ghasemi, R. S., Madrakian, H., \& Keivani, F. S. (2013). The Relationship between the corporate governance and the stock institutional ownership with the dividend - A case study of Tehran. Journal of Business and Management, 15(2), 65-69. https://doi.org/10.9790/487X-1526569

Goodstein, J., Gautam, K., \& Boeker, W. (1994). The effects of board size and diversity on strategic change. Strategic Management Journal, 15(3), 241-250. https://doi.org/10.1002/smj.4250150305

Hutchinson, M., Mack, J., \& Plastow, K. (2015). Who selects the 'right'directors? An examination of the association between board selection, gender diversity and outcomes. Accounting \& Finance, 55(4), 1071-1103. https://doi.org/10.1111/acfi.12082

Inyiama, E. C., Okwo, M. I., \& Inyiama, O. I. (2015). Dividend Payout Policy Determinants of Selected Listed Brewery Firms in Nigeria. European Journal of Business, Economics and Accountancy, 3(3), 101-118.

Jebaraj, B. S. (2019). Board gender composition, dividend policy and COD: the implications of CEO duality. Accounting Research Journal, 32(3), 454-476. https://doi.org/10.1108/ARJ-02-2018-0035

Kaleem, A., \& Salahuddin, C. (2006). Impact of dividend announcement on common stock prices at Lahore Stock Exchange (Pakistan). South Asian Journal of Management, 13(2), 86.

Kowalewski, O., Stetsyuk, I., \& Talavera, O. (2008). Does corporate governance determine dividend payouts in Poland?. Post-Communist Economies, 20(2), 203-18. https://doi.org/10.1080/14631370802018973

Kulathunga, K. M. K. N. S., \& Azeez, A. A. (2016). The Impact of Ownership Structure on Dividend Policy: Evidence From Listed Companies In Sri Lanka. https://doi.org/10.5176/2251-2012_QQE16.43

Lasfer, M. A. (1995). Ex-day behavior: tax or short-term trading effects. The Journal of Finance, 50(3), 875-897. https://doi.org/10.1111/j.1540-6261.1995.tb04040.x

Linter, J. (1956). Distribution of incomes of corporations among dividends, retained earnings and taxes. The American Economic Review, 46, 97-113.

Litai, C., \& Zuniu, Z. (2011). The service industrial agglomeration and regional economic growth in China based on the perspective of labor productivity. Science Research Management, (12), 18.

Lonie, A. A., Abeyratna, G., Power, D. M., \& Sinclair, C. D. (1996). The stock market reaction to dividend announcements: A UK study of complex market signals. Journal of Economic Studies, 23(1), 32-52. https://doi.org/10.1108/01443589610106534

Mansourinia, E., Emamgholipour, M., Rekabdarkolaei, E. A., \& Hozoori, M. (2013). The effect of board size, board independence and CEO duality on dividend policy of companies. International Journal of Economy, Management and Social Sciences, 2(6), 237-241.

McCluskey, T. G. (2005). An empirical investigation of the dividend decision in Irish companies. Doctoral dissertation, University of Dundee.

Miller, M., \& Modigliani, F. (1961). Dividend policy, growth, and the valuation of shares. The Journal of Business, 34(4), 411-433. https://doi.org/10.1086/294442

Mintzberg, H., \& Mintzberg, H. (1983). Power in and around organizations (Vol. 142, pp. 1-23). Prentice-Hall Englewood Cliffs, NJ.

Nash, R. C., Netter, J. M., \& Poulsen, A. B. (2003). Determinants of contractual relations between shareholders and bondholders: investment opportunities and restrictive covenants. Journal of Corporate Finance, 9(2), 201-232. https://doi.org/10.1016/S0929-1199(02)00007-X

Nicholson, G., \& Kiel, G. C. (2003). Board Composition and Corporate Performance: How the Australian Experience Informs Contrasting Theories of Corporate Governance. Corporate Governance: An International Review, 11(3), 189-205. https://doi.org/10.1111/1467-8683.00318

Nielsen, S., \& Huse, M. (2010). The contribution of women on boards of directors: Going beyond the surface. $\begin{array}{lllll}\text { Corporate } \quad \text { Governance: } & \text { An } & \text { International } & \text { 136-148. }\end{array}$ 
https://doi.org/10.1111/j.1467-8683.2010.00784.x

Oxelheim, L., Randoy, T., \& Thomsen, S. (2006, November). A Nordic Perspective on Corporate Board Diversity. Nordic Innovation Centre.

Ozdagli, A. K. (2009). Financial Leverage, Corporate Investment, and Stock Returns. FRB of Boston Working Paper No. 09-13. https://doi.org/10.2139/ssrn.1518591

Ozkan, A., \& Mancinelli, L. (2006). Ownership structure and dividend policy: Evidence from Italian firms. European Journal of Finance, 12(3), 265-282. https://doi.org/10.1080/13518470500249365

Pruitt, S. W., \& Gitman, L. J. (1991). The interactions between the investment, financing, and dividend decisions of major US firms. Financial Review, 26(3), 409-430. https://doi.org/10.1111/j.1540-6288.1991.tb00388.x

Rajverma, A. K., Arrawatia, R., Misra, A. K., Chandra, A., \& Mcmillan, D. (2019). Ownership structure influencing the joint determination of dividend, leverage, and cost of capital. Cogent Economics \& Finance, 7(1), 1-25. https://doi.org/10.1080/23322039.2019.1600462

Rose, C. (2007). Does female board representation influence firm performance? The Danish evidence. Corporate Governance: An International Review, 15(2), 404-413. https://doi.org/10.1111/j.1467-8683.2007.00570.x

Shaukat, A., Qiu, Y., \& Trojanowski, G. (2016). Board Attributes, Corporate Social Responsibility Strategy, and Corporate Environmental and Social Performance. Journal of Business Ethics, 135(3), 569-585. https://doi.org/10.1007/s10551-014-2460-9

Subramaniam, R. K., Devi, S. S., \& Marimuthu, M. (2011). Investment opportunity set and dividend policy in Malaysia. African Journal of Business Management, 5(24), 10128-10143.

Uddin, M. H., \& Chowdhury, G. M. (2005). Effect of dividend announcement on shareholders' value: Evidence from Dhaka Stock Exchange. Journal of Business Research, 7(1), 61-72.

Uwalomwa, U., Olamide, O., \& Francis, I. (2015). The Effects of Corporate Governance Mechanisms on Firms Dividend Payout Policy in Nigeria. Journal of Accounting and Auditing: Research \& Practice, 1-12. https://doi.org/10.5171/2015.313679

Woolridge, J. R., \& Ghosh, C. (1985). Dividend cuts: Do they always signal bad news. Midland Corporate Finance Journal, 3(2), 20-32.

Ye, D., Deng, J., Liu, Y., Szewczyk, S. H., \& Chen, X. (2019). Does board gender diversity increase dividend payouts? Analysis of global evidence. Journal of Corporate Finance, 58, 1-26. https://doi.org/10.1016/j.jcorpfin.2019.04.002

Zahra, S. A. (1988). The implications of board of directors composition for corporate strategy and performance. International Journal of Management, 5(2), 229-236.

Zeng, T. (2003). What determines dividend policy: a comprehensive test. Journal of American Academy of Business, Cambridge, 2(2), 304. 